\title{
EFFECT OF THE ESSENTIAL OIL FROM CORIANDER (CORIANDRUM SATIVUM SEEDS) ON MORPHINE ANTINOCICEPTION TOLERANCE AND WITHDRAWAL SYNDROME IN MICE
}

\author{
ELMIRA BAROTYHA ${ }^{1}$, HAMED SHAFAROODI ${ }^{2} *$, JINOUS ASGARPANAH ${ }^{1}$ \\ ${ }^{I}$ Department of Pharmacognosy, Faculty of Pharmacy and Pharmaceutical Sciences, Tehran Medical Sciences, Islamic Azad \\ University, Tehran, Iran \\ ${ }^{2}$ Department of Pharmacology, School of Medicine, Tehran University of Medical Sciences, Tehran, Iran
}

*corresponding author: hshafaroodi@sina.tums.ac.ir

Manuscript received: September2020

\begin{abstract}
The study was designed to evaluate the effects of coriander essential oil (CEO) on morphine dependence and tolerance. To evaluate the effect of CEO on the induction of morphine dependence and tolerance, CEO $(2.5 \mathrm{mg} / \mathrm{kg} \mathrm{bw})$ and clonidine $(0.1$ $\mathrm{mg} / \mathrm{kg} \mathrm{bw}$ ) as the positive control were injected i.p. To determine the expression of morphine dependence and tolerance, all compounds were injected once i.p. on the day of the experiment. The effect of CEO and other agents on the dependence was evaluated by counting the number of jumps and standings, defecation and weight loss induced by naloxone (5 mg/kg bw) while the tolerance was evaluated by the tail-flick test. Clonidine reduced the severity of withdrawal signs in the expression phase. Results indicated that CEO had significant effects on morphine tolerance and dependence.
\end{abstract}

\section{Rezumat}

Studiul a evaluat efectele uleiului esențial de coriandru (CEO) asupra dependenței și toleranței la morfină, într-un model experimental murin. Pentru a evalua efectul CEO asupra inducerii dependenței și toleranței la morfină, s-au injectat i.p., în doză unică, CEO (2,5 mg/kg corp) și clonidină $(0,1 \mathrm{mg} / \mathrm{kg}$ corp), controlul pozitiv. Efectul farmacologic privind dependența a fost evaluat prin determinarea numărului de mișcări, a defecației și pierderea în greutate indusă de naloxonă (5 mg/kg corp), în timp ce toleranța a fost evaluată prin testul tail-flick. Clonidina a redus severitatea semnelor de sevraj în faza de expresie. Rezultatele au indicat că CEO a avut efecte semnificative asupra toleranței și dependenței la morfină, în modelul ales.

Keywords: Coriandrum sativum, essential oil, morphine, dependence, tolerance

\section{Introduction}

The development of tolerance and physical dependence is a characteristic feature of all the opioid drugs such as morphine. Tolerance refers to a decrease in the effects of an agent following repeated exposure, while dependence may be defined as the necessity for an agent to maintain normal physiological functions [1]. Opioid tolerance and dependence should be considered as biphasic patterns each consisting of two phases: development and expression [1]. Tolerance to the analgesic properties of opioids such as morphine is one of the most common complications in patients with chronic pain and leads to the need to increase the dose of morphine, so side effects such as sedation, constipation and, rarely, seizures, and myoclonus appear [2].

Coriandrum sativum L. belongs to the Apiaceae family and is native to many parts of the world including the Mediterranean and Middle Eastern region. The seeds are commonly called as coriander while the leaves are called as Cilantro. Coriander is widely used for seasoning food and beverages [3]. The coriander extract has been previously reported to be a significant painkiller [4]. It was indicated that the extract $(250,500$, and $1000 \mathrm{mg} / \mathrm{kg} \mathrm{bw})$ had modulator effects on pain. Taherian et al. findings provided the evidence for the existence of an interaction between antinociceptive effects of the coriander extract and opiate system [4]. According to the previous studies linalool as the major component of coriander essential oil (CEO) was indicated to have a significant effect on morphine tolerance and dependence [5]. Regarding that and considering the high content of essential oil in the coriander we were prompted to investigate the effect of the CEO on morphine tolerance and dependence in mice.

\section{Materials and Methods}

Chemicals

Chemicals used were clonidine (Toliddaru-Iran), naloxone hydrochloride (Toliddaru-Iran), morphine sulphate (Temad-Iran).

Plant material

Coriander (seeds) was purchased in November 2018 from the local market in Qazvin Province, Iran. The specimen was identified by N. Kazemivash and a 
FARMACIA, 2021, Vol. 69, 4

voucher was deposited in the Herbarium of the Faculty of Pharmacy, Tehran Medical Sciences, Islamic Azad University under the code number 437-PMPIA.

\section{Essential oil extraction}

The fully ripped seeds were submitted to the hydrodistillation in a Clevenger-type apparatus for 2 hours. At the end of the distillation, the CEO was collected, dried on anhydrous $\mathrm{Na}_{2} \mathrm{SO}_{4}$ and kept in glass vials at $-18^{\circ} \mathrm{C}$ for further analysis.

Analysis of the essential oil

Analysis of the oil sample was performed on a HP6890 gas chromatograph (GC) equipped with a FID and a DB-5 capillary column, $30 \mathrm{~m} \times 0.25 \mathrm{~mm}$, $0.25 \mu \mathrm{m}$ film thickness, temperature programmed as follows: $60-240^{\circ} \mathrm{C}$ at $4^{\circ} \mathrm{C} / \mathrm{min}$. The carrier gas $\mathrm{N}_{2}$ was at a flow of $2.0 \mathrm{~mL} / \mathrm{min}$; the temperatures of injector port and detector were $250^{\circ} \mathrm{C}$ and $300^{\circ} \mathrm{C}$, respectively. Samples were injected by splitting and the split ratio was 1:10. The analysis of GC/MS was performed on a Hewlett-Packard 6890/5972 system with a DB-5 capillary column $(30 \mathrm{~m} \times 0.25 \mathrm{~mm}$; $0.25 \mu \mathrm{m}$ film thickness. The operating conditions were the same conditions as described above, but the carrier gas was He. Mass spectra were taken at $70 \mathrm{eV}$. The range of scan mass was from 40-400 $\mathrm{m} / \mathrm{z}$ at a sampling rate of $1.0 \mathrm{scan} / \mathrm{s}$. Quantitative data were obtained from the electronic integration of the FID peak areas. The components of the oil were identified by their retention time, retention indices, relative to $\mathrm{C}_{9}-\mathrm{C}_{28} \mathrm{n}$-alkanes, computer matching with the WILEY275.L library and as well as by comparison of their mass spectra with those of authentic samples or with data already available in the literature $[6,7]$. The percentage of composition of the identified compounds was computed from the GC peaks areas without any correction factors and was calculated relatively. Animals

Adult male albino mice weighing 20 - $30 \mathrm{~g}$ were obtained from the animal house of Tehran University of Medical Sciences. They were maintained on normal diet in the animal house at the temperature of $21 \pm$ $2^{\circ} \mathrm{C}$ and light/dark cycle of $12 / 12$ hours. Groups of 8 mice were chosen randomly for the studies. All procedures were carried out in accordance with the Law 11,794, of October 8, 2008 by the National Council of Animal Experimentation Control (CONCEA).

Development of dependence and tolerance

Morphine dependence was developed in mice by a repeated-injections schedule. Morphine was injected subcutaneously (s.c.) to each mouse at doses of 50,50 , and $75 \mathrm{mg} / \mathrm{kg}$ bw three times daily (8:00 a.m., 12:00 and 16:00 p.m., respectively) for 3 days. On the fourth day a single dose of morphine (50 mg/kg bw) was injected (i.p.) [5]. Physical dependence was assessed following the i.p. administration of a $5 \mathrm{mg} / \mathrm{kg}$ bw dose of naloxone. After the injection of naloxone, the animals were immediately observed on a platform (40 cm long, $25 \mathrm{~cm}$ wide and $45 \mathrm{~cm}$ high) for $30 \mathrm{~min}$ and then the number of jumps and standings, weight loss and defecation were recorded. The antinociceptive activity following acute morphine administration $(5 \mathrm{mg} / \mathrm{kg}$ bw) was assessed in the tail-flick test as described above [5]. The loss of the antinociceptive effects of morphine in the tail-flick test was used to assess the degree of tolerance. Morphine tolerance was developed in mice by a repeated-injections schedule. Morphine was injected subcutaneously (s.c.) to each mouse at doses of 5 , and $5 \mathrm{mg} / \mathrm{kg}$ bw twice daily (8:00 a.m., 12:00 and, respectively) for 3 days. On the fourth day a single dose of morphine (5 mg/kg bw) was injected (i.p.) [5]. The tail-flick latency was assessed $30 \mathrm{~min}$ after an injection of $5 \mathrm{mg} / \mathrm{kg}$ bw of morphine. The animals were briefly restrained with their tail positioned in an apparatus (type 812, Hugo Sachs Electronics, Germany) for radiant heat stimulation on the dorsal surface of the tail. Tail-flick latency was defined as the time interval between the application of a standardized beam focused on the tail and the abrupt removal of the tail from the nociceptive stimulus.

The acute antinociceptive activity of morphine (1, $2.5,5$ and $10 \mathrm{mg} / \mathrm{kg} \mathrm{bw}$ ) was determined in one day by tail-flick test. Morphine showed antinociceptive activity at a dose of $5 \mathrm{mg} / \mathrm{kg}$ bw. To induce the morphine tolerance model in mice, the effective dose of morphine $(5 \mathrm{mg} / \mathrm{kg} \mathrm{bw})$ was administrated twice daily for 3 days. The chronic antinociceptive activity of morphine was assessed by tail-flick test in the fourth day and $30 \mathrm{~min}$ after the injection of a single dose of $5 \mathrm{mg} / \mathrm{kg}$ bw morphine.

Antinociception activity of CEO

Moreover, the analgesic effect of different single doses of CEO $(2.5,5,10$ and $20 \mathrm{mg} / \mathrm{kg}$ bw) was evaluated on four groups of mice to determine whether or not, CEO possesses an intrinsic antinociceptive effect. These animals did not receive any other drugs.

\section{Evaluation of dependence to morphine}

The animals were divided into 3 groups $(\mathrm{n}=8$ each): Group 1 (negative control) received morphine and vehicle (normal saline). Group 2 received morphine and a single dose of CEO $(2.5 \mathrm{mg} / \mathrm{kg} \mathrm{bw})$ on the fourth day. Group 3 (positive control) clonidine $(0.1 \mathrm{mg} / \mathrm{kg} \mathrm{bw})$ on the fourth day.

Two hours after the injection of the last dose of morphine on the fourth day, naloxone $(5 \mathrm{mg} / \mathrm{kg} \mathrm{bw}$, i.p.), the selective antagonist of opioid receptors, was injected to the animals (groups 1 - 3) to precipitate the withdrawal syndrome. Mice were immediately placed individually in a plexiglass box and the number of jumps and standings, weight loss and defecation as major signs of withdrawal syndrome, were recorded during a $30 \mathrm{~min}$ period of time [8].

Evaluation of tolerance to morphine

The animals were divided into 4 groups $(n=8$ each): Group 4 (control) CEO vehicle (sweet 
almond oil) on the fourth day. Group 5 received morphine and a single dose of CEO $(2.5 \mathrm{mg} / \mathrm{kg} \mathrm{bw})$ on the fourth day. Group 6 received morphine and CEO $(2.5 \mathrm{mg} / \mathrm{kg} \mathrm{bw})$ three times per day on days 1 , 2 , and 3 , but not on day 4 . Group 7 received morphine and the vehicle three times a day on days 1,2 , and 3 but not on day 4 .

In order to assess the development of tolerance to analgesic effects of morphine in control or CEOtreated mice, the tail-flick test was used. $30 \mathrm{~min}$ after the injection of morphine $(5 \mathrm{mg} / \mathrm{kg}$ bw, i.p.) the mice were assessed by the mentioned test in a single day. The latency of nociceptive responses in mice was expressed as the tail-flick latency.
To evaluate the effect of CEO on the expression of the tolerance to morphine, a single dose of CEO (2.5 $\mathrm{mg} / \mathrm{kg}$ bw, i.p.) was administered $30 \mathrm{~min}$ before the injection of the last dose of morphine ( 5 $\mathrm{mg} / \mathrm{kg}$ bw, i.p.) on the fourth day. These animals (group 4) did not receive CEO before the injection of morphine during the 3-day administration schedule. Moreover, to assess the effects of CEO on the development of morphine tolerance, the repeated dose of CEO $(2.5 \mathrm{mg} / \mathrm{kg}$ bw, i.p. $)$ was administered $30 \mathrm{~min}$ before the injection of morphine during the 3-day administration schedule. These animals (group 6) did not receive CEO before the injection of morphine on the fourth day (Figure 1).

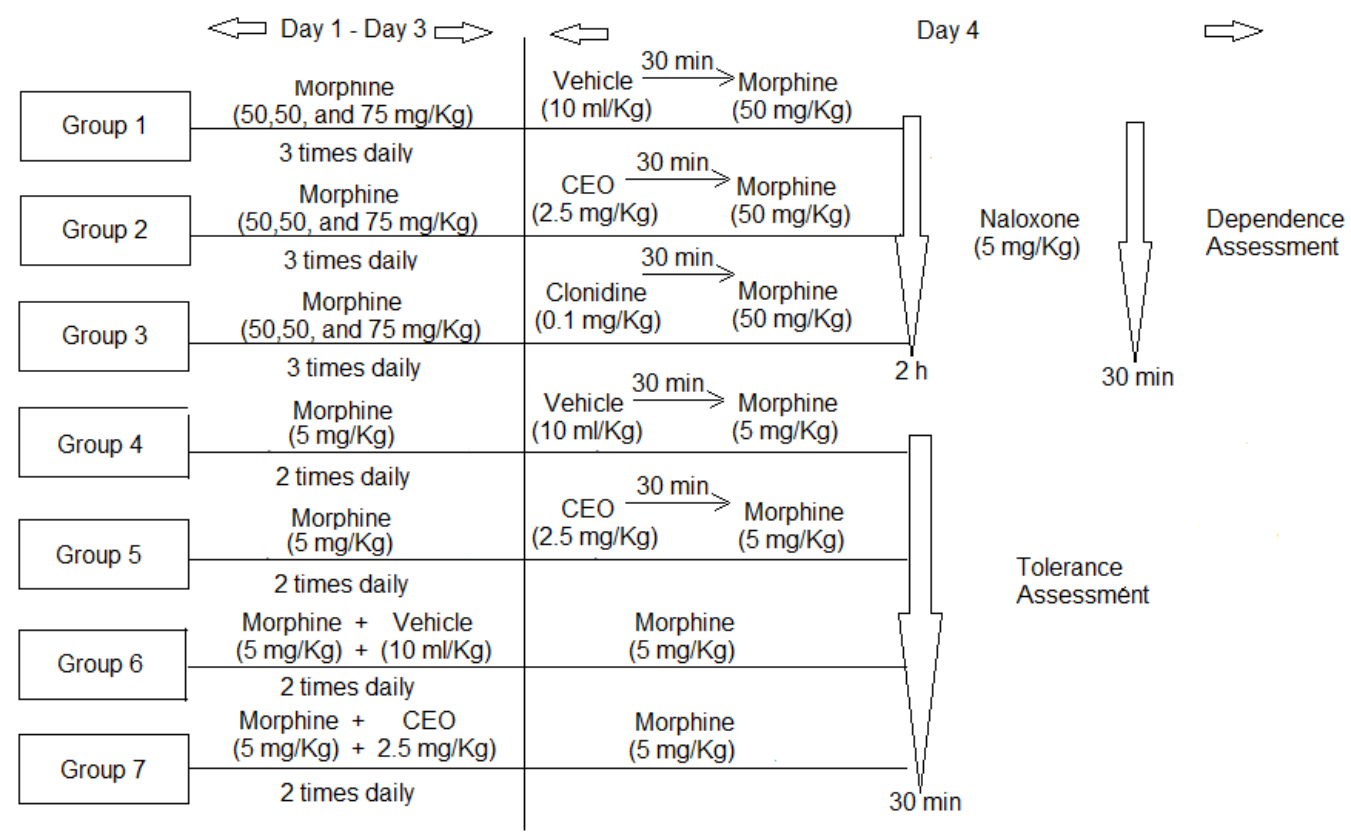

Figure 1.

Evaluation of the dependence and tolerance to morphine under CEO treatment

\section{Statistical analysis}

All data are presented as the mean \pm SEM of the value for the corresponding parameters. Statistical comparison between groups in each experiment was performed by one-way analysis of variance (ANOVA) followed by Tukey-Kramer test for multiple comparison. A value of $p<0.05$ was considered significant.

\section{Results and Discussion}

The hydrodistillation of coriander seeds resulted in a colourless oil with pleasant odour, with an yield of $4.8 \%(\mathrm{v} / \mathrm{w})$ based on the fresh weight. As shown in the Table I, 18 components were identified in this oil which represented about $98.7 \%$ of the total chromatographical material. The major constituent of the oil was linalool $(80.6 \%)$.
The results of antinociceptive activity showed that CEO at three dose levels of 5,10 , and $20 \mathrm{mg} / \mathrm{kg}$ bw indicated significant antinociceptive activity $\left({ }^{*} \mathrm{p}<\right.$ $0.05, * * \mathrm{p}<0.01$ and $* * * \mathrm{p}<0.001$ respectively). As result, the inactive dose of CEO was determined as $2.5 \mathrm{mg} / \mathrm{kg}$ bw (Figure 2).

The Figure 3 shows the antinociceptive effects of morphine in tail-flick test.

CEO at a dose of $2.5 \mathrm{mg} / \mathrm{kg}$ bw and clonidine $(0.1$ $\mathrm{mg} / \mathrm{kg} \mathrm{bw}$ ) increased the reaction time compared with morphine-treated animals that received vehicle and chronic morphine on the test day (Figure 4). CEO did not lead to inhibition of morphine tolerance during the development period while it led to inhibition of morphine tolerance during the expression period with a dose of $2.5 \mathrm{mg} / \mathrm{kg}$ bw $(* * * \mathrm{p}<0.001)$. Also, clonidine was effective in the reduction of morphine dependence symptoms (Figure 4). 


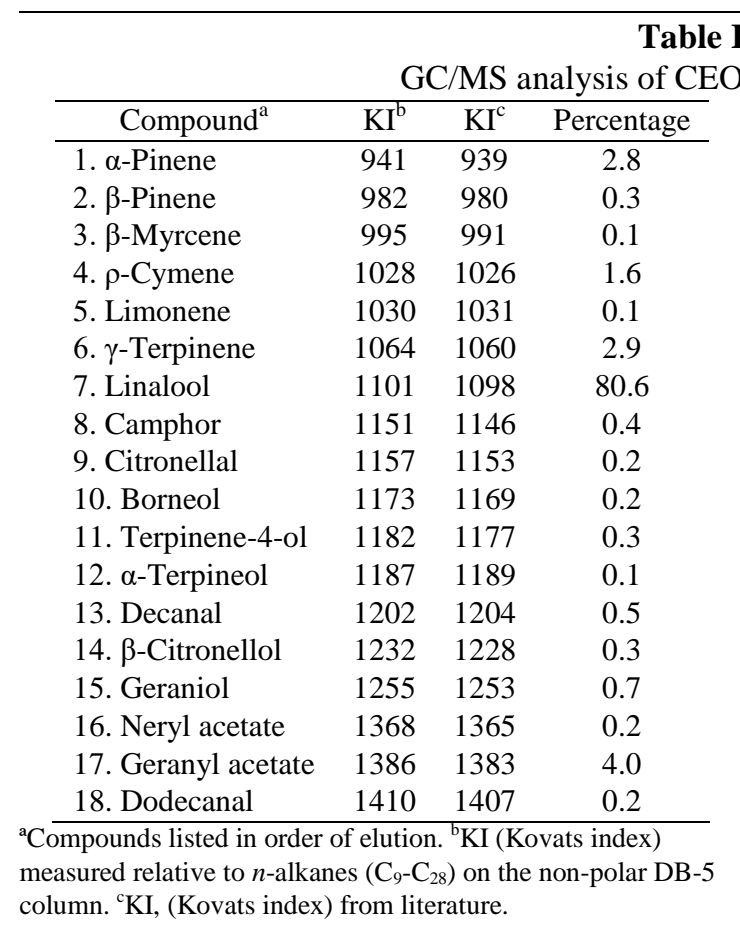

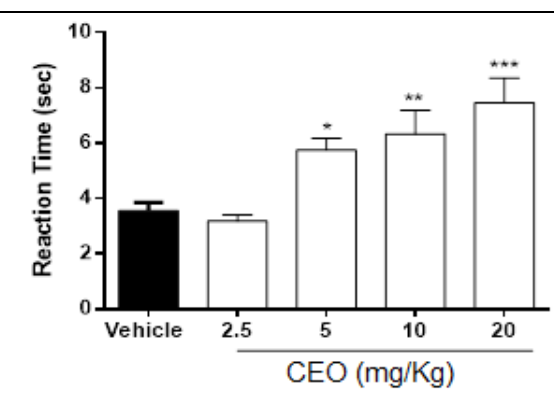

Figure 2.

The antinociceptive activity of different doses of CEO

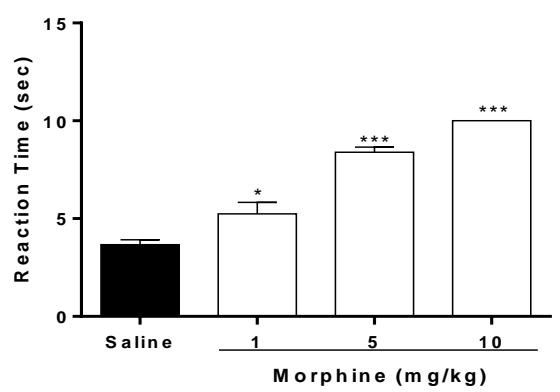

Figure 3.

The antinociceptive effects of morphine in tail-flick test

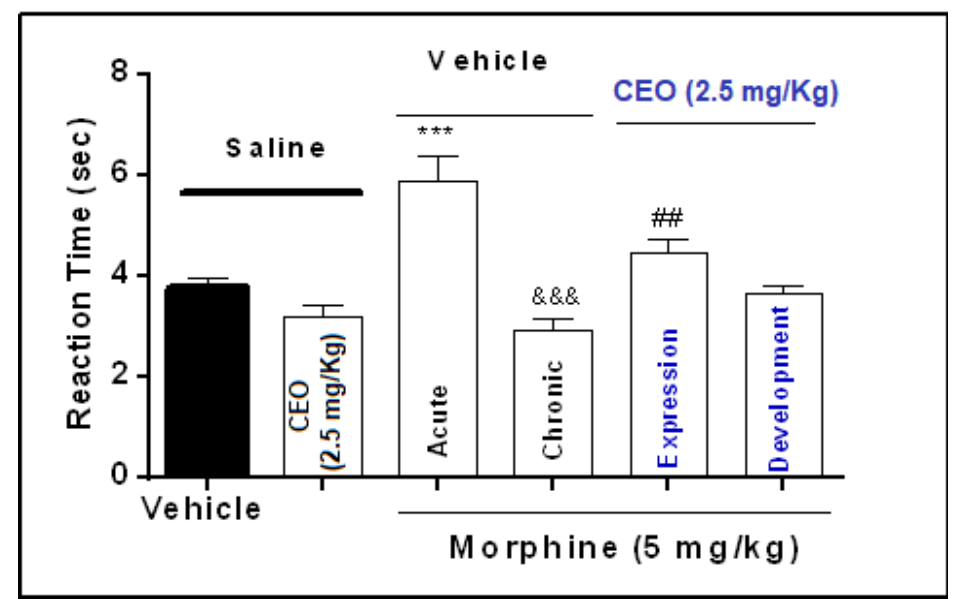

Figure 4.

The effect of CEO on expression of morphine tolerance in mice. The animals received morphine (50 and 50, $\mathrm{mg} / \mathrm{kg}$ bw 3 times/day for 3 days) for the induction of morphine tolerance. On the next day, the animals received CEO $(2.5 \mathrm{mg} / \mathrm{kg}$ bw i.p.), vehicle and morphine $(5 \mathrm{mg} / \mathrm{kg} \mathrm{bw})$ and the tail-flick test was carried out to evaluate the effect of CEO on the expression of morphine tolerance. Each group comprised 8 mice

***p $<0.001$ compared with the vehicle group. ${ }^{p} \mathrm{p}<0.05$ compared with the chronic tolerance to morphine. The TukeyKramer test was used for multiple comparisons.

The effect of CEO on the development of morphine tolerance in mice. The animals received morphine (50 and 50, $\mathrm{mg} / \mathrm{kg}$ bw/day for 3 days) for induction of morphine tolerance and $30 \mathrm{~min}$ before each dose of morphine received CEO $(2.5 \mathrm{mg} / \mathrm{kg}$ i.p. $)$ and the vehicle. On the next day, the animals received morphine $(5 \mathrm{mg} / \mathrm{kg} \mathrm{bw})$ and the tail-flick test was carried out to evaluate the effect of CEO on the development of morphine tolerance. Each group comprised 8 mice. ${ }^{\& \& \&} p<0.001$ compared with the vehicle group. ${ }^{\# \#} \mathrm{p}<0.01$ compared with the chronic tolerance to morphine. Tukey-Kramer test was used for multiple comparisons.

CEO (2.5 mg/kg bw) and clonidine significantly reduced the withdrawal signs except weight loss ( $\mathrm{p}$ $<0.01$ and $\mathrm{p}<0.01$, respectively) (Figure 5). 

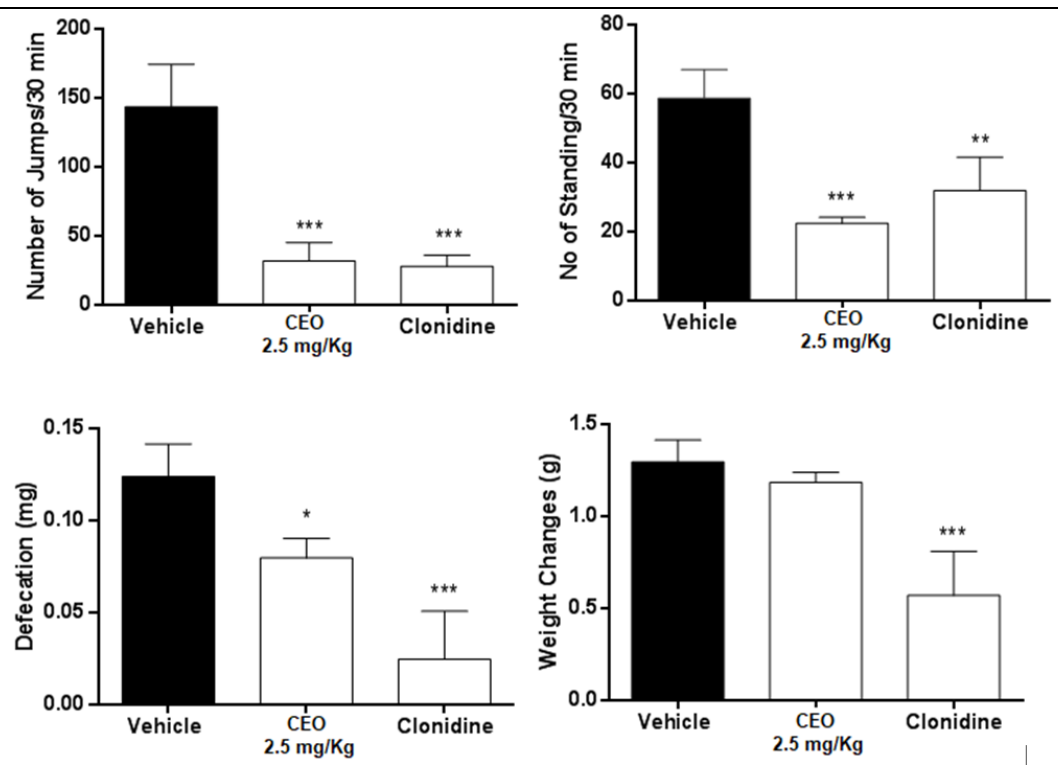

Figure 5.

The effect of CEO on the morphine dependence in mice. The animals received morphine (50, $50 \mathrm{and} 75 \mathrm{mg} / \mathrm{kg}$

bw/day for 3 days) for development of morphine dependence and $30 \mathrm{~min}$ prior to each dose of morphine received CEO $(2.5 \mathrm{mg} / \mathrm{kg} \mathrm{bw})$, clonidine $(0.1 \mathrm{mg} / \mathrm{kg} \mathrm{bw})$ and the vehicle. Naloxone $(5 \mathrm{mg} / \mathrm{kg} \mathrm{bw})$ was used on day 4 for the withdrawal signs. Each group comprised 8 mice

$* \mathrm{p}<0.05, * * \mathrm{p}<0.01$ and $* * * \mathrm{p}<0.001$ compared with the vehicle group

Different preparations made from coriander are commonly used in ethnobotanical practices for the treatment of pain and inflammation disorders in Iran. The extract of coriander has been previously reported to be effective on pain with interacting the opioid system [4]. Regarding the high content of essential oil in the coriander we were prompted to investigate the effect of the CEO on morphine tolerance and dependence in mice.

Compounds affecting neurotransmitter systems such as the alpha-2 adrenergic agonist, NMDA receptor antagonists, dopamine antagonists, $\gamma$ aminobutyric acid (GABA) agonist, adenosine agonist, 5-HT2A/C receptor antagonists can alleviate somatic and affective withdrawal signs of opioids [9]. Clonidine (alpha-2 adrenoceptor agonist) is used to reduce the opioid withdrawal syndrome [10]. In the current study, the clonidine as a positive control, reduced dependence induced by morphine. Several compounds and systems, including NMDA receptor antagonists and the noradrenergic system can also reduce the tolerance and dependence induced by opioids [11].

The current results indicated that CEO reduced the severity of withdrawal signs except weight loss. CEO was as effective as the positive control, clonidine. The phytochemical results indicated that the observed effects of CEO may be due to its content of linalool. Linalool was characterized as the main component of the oil (80.6\%). This component was indicated to have significant effect on morphine tolerance and dependence. It has been shown that linalool inhibits NMDA receptors [12-
14] and its effect on the reduction of morphine tolerance and dependence may be related partially to the inhibition of NMDA receptors [5]. The antinociceptive activity of linalool as the major component of $\mathrm{CEO}$ was shown to be inhibited by the Adenosine $\mathrm{A} 1$ and $\mathrm{A} 2 \mathrm{~A}$ receptor antagonists in the hot-plate test. These findings demonstrated that the effect of linalool on the pain response is, at least partially, mediated by the activity of adenosine A1 and A2A receptors [14]. Adenosine A1 receptor agonists such as 2-chloroadenosine and Rphenylisopropyladenosine suppressed the withdrawal syndrome of morphine [15]. It may be possible that linalool decreased morphine dependency and tolerance through an adenosine dependent mechanism.

Linalool modulates a wide variety of neurotransmitter systems and signal transduction such as opioid, dopamine, muscarinic and adenosine receptors and $\mathrm{K}_{\mathrm{ATP}}$ channels as well as nitric oxide signalling $[16,17]$. Linalool reduced nitric oxide (NO) production/release in the culture medium [13]. As NO plays an important role in tolerance to the analgesic effect of morphine, it is possible, at least partially, that this effect was also involved in linalool activity [18]. Nitric oxide (NO) production, as an intercellular messenger, is closely related to glutamate $\mathrm{N}$-methyl-D-aspartate (NMDA) receptors [19]. Thus, it is possible that a key role for the mechanism of the linalool rich essential oil of coriander is mediated via NMDA receptors. 


\section{Conclusions}

As conclusion, the current study suggests that the linalool rich essential oil of coriander plays a major role in the reduction of expression of tolerance and dependence induced by morphine. The results also suggest that CEO possesses a biologically active constituent (linalool) that has significant activity to reduce morphine expression tolerance and dependency. CEO may be used as a therapeutic agent to alleviate these side effects, the dependence and tolerance to morphine and other opioids in patients with opioid abuse. The current research supports the ethnomedicinal claims of coriander application in the relief of opioid abuse.

\section{Conflict of interest}

The authors declare no conflict of interest.

\section{References}

1. Homayoun $\mathrm{H}$, Khavandgar $\mathrm{S}$, Namiranian $\mathrm{K}$, Dehpour AR, The effect of cyclosporin A on morphine tolerance and dependence: involvement of L-arginine/nitric oxide pathway. Eur $J$ Pharmacol., 2002; 452: 67-75.

2. Popik P, Kozela E, Danysz W, Clinically available NMDA receptor antagonists memantine and dextromethorphan reverse existing tolerance to the antinociceptive effects of morphine in mice. Naunyn-Schmiedeberg's Arch Pharmacol., 2000; 361: 425-432.

3. Facciola S, Cornucopia: A Source Book of Edible Plants. Kampong Publications, 1990.

4. Taherian AA, Vafaei AA, Ameri J, Opiate system mediate the antinociceptive effects of Coriandrum sativum in mice. Iran J Pharm Res., 2012; 11(2): 679-688.

5. Hosseinzadeh $\mathrm{H}$, Imenshahidi $\mathrm{M}$, Hosseini $\mathrm{M}$, Razavi BM, Effect of Linalool on morphine tolerance and dependence in mice. Phytother Res., 2012; 26: 1399-1404.

6. Swigar A, Silverstein R, Monoterpenes. Aldrich Chemical Company. Inc, Milwaukee, Wisconsin, USA. 1981; 130.

7. Adams R, Identification of essential oil components by gas chromatography/mass spectroscopy. $J A m$ Soc Mass Spect., 1997; 6(8): 671-2.

8. Hosseinzadeh $\mathrm{H}$, Parvardeh S, Masoudi A, Moghimi M, Mahboobifard F, Attenuation of morphine tolerance and dependence by thymoquinone in mice. Avicenna J Phytomed., 2016; 6: 55-66.

9. Harris AC, Gewirtz JC, Acute opioid dependence: characterizing the early adaptations underlying drug withdrawal. Psychopharmacol., 2005; 178: 353-366.

10. Chen S, Zhai H, Cui Y, Shi J, Lefoll B, Lu L, Clonidine attenuates morphine withdrawal and subsequent drug sensitization in rhesus monkeys. Acta Pharmacol Sinica, 2007; 28: 473-483.

11. Hosseinzadeh H, Lary P, Effect of Salvia leriifolia leaf extract on morphine dependence in mice. Phytother Res., 2000; 14: 384-387.

12. Elisabetsky E, Marschner J, Onofre Souza D, Effects of linalool on glutamatergic system in the rat cerebral cortex. Neurochem Res., 1995; 20: 461465.

13. Peana AT, Marzocco S, Popolo A, Pinto A, (-) Linalool inhibits in vitro NO formation: Probable involvement in the antinociceptive activity of this monoterpene compound. Life Sci., 2006; 78: 719723.

14. Peana AT, Rubattu P, Piga GG, Fumagalli S, Boatto G, Pippia P, De Montis MG, Involvement of adenosine $\mathrm{A} 1$ and $\mathrm{A} 2 \mathrm{~A}$ receptors in (-)-linaloolinduced antinociception. Life Sci., 2006; 78: 24712474.

15. Michalska E, Malec D, Agonist and antagonists of adenosine receptors and morphine withdrawal syndrome in rats. Pol J Pharmacol., 1993; 45: 1-9.

16. Peana AT, Graziella De Montis M, Sechi S, Sircana G, D'Aquila PS, Pippia P, Effects of (-)linalool in the acute hyperalgesia induced by carrageenan, glutamate and prostaglandin E2. Eur J Pharmacol., 2004; 497: 279-284.

17. Peana AT, De Montis MG, Nieddu E, Spano MT, D'Aquila PS, Pippia P, Profile of spinal and supraspinal antinociception of (-)-linalool. Eur $J$ Pharmacol., 2004; 485: 165-174.

18. Ozdemir E, Bagcivan I, Durmus N, Altun A, Gursoy S, The nitric oxide-cGMP signaling pathway plays a significant role in tolerance to the analgesic effect of morphine. Can J Physiol Pharmacol., 2011; 89: 89-95.

19. Frade JG, Barbosa RM, Laranjinha J, Stimulation of NMDA and AMPA glutamate receptors elicits distinct concentration dynamics of nitric oxide in rat hippocampal slices. Hippocamp., 2009; 19: 603611. 